\title{
STUDIES ON THE PARASITES OF CARDIUM EDULE L.: CERCARIA FULBRIGHTI N.SP., A GYMNOPHALLUS LARVA WITH A FORKED TAIL
}

\author{
By Robert F. Hutton \\ From the Plymouth Laboratory \\ (Plate I and Text-figs. I-2)
}

An examination of 420 specimens of Cardium edule L., collected at Millbrook, Plymouth, England, revealed a species of marine cercaria differing from any other larval trematode which has been described. This parasite was present in five of the 420 specimens. The name Cercaria fulbrighti is given to this species in honour of U.S. Senator J. William Fulbright of Arkansas.

This work was carried out at the Plymouth Laboratory of the Marine Biological Association while the author was holding a Fulbright Scholarship.

I am grateful to Dr V. Fretter and Dr B. Dawes for reading and criticizing the manuscript. In addition to thanking Dr J. S. Alexandrowicz for reading and offering valuable criticism for the improvement of my manuscript, I am indebted to him for taking the photomicrographs.

\section{The Trematode Parasites of Cardium edule L.}

Table I contains a summary of the trematode parasites which have been recorded from the cockle. In the table there is some doubt as to whether Cercaria dichotoma Müller and C. fissicauda La Valette St. George are different species: they may represent, as Lebour (I9I2) considered them, only one; or, if two, they are closely related. Pelseneer (I906), reporting

\section{TABLE I}

Parasite

Bucephalopsis gracilescens = Bucephalus haimeanus Cercaria dichotoma

C. fissicauda

Parorchis acanthus $=$ Cercaria purpurae sp.inq. Himasthla leptosoma $=$ Echinostomum secundum Cercaria mytili sp.inq. C. strigata Lepidapedon rachion? = Lepodora rachiaea? Cercaria margaritae sp.inq. C. cambrensis
Author

(Rudolphi, I8I9) Lacaze-Duthiers, I854 Müller (according to La Valette

St. George, 1855)

La Valette

St. George, I855

(Nicoll, I906)

Lebour, I9I2

(Creplin, I829)

Nicoll, r906

Lebour, I9I2

Lebour, I908

(Cobbold, r858)

(Cobbold, I858)

Lebour, I9I2

Cole, I938

\section{Reported by}

Lebour, I912; etc.

Pelseneer, I906; etc.

Johnstone, I904

Lebour \& Elmhirst, I922

Lebour, I9I2?

Lebour, I9r 2

Rees, I939

Lebour, I9I 2

Lebour, I9I2

Cole, I938
Encystment

Sporocyst

Sporocyst

Sporocyst

Sporocyst?

Encystment

Encystment

Encystment

Sporocyst

Sporocyst

Sporocyst Sporocyst 
C. dichotoma from Cardium edule (and from several other bivalves), and believing but one species to be involved, gives the following evidence as to why the name Cercaria fissicauda should be suppressed in favour of $C$. dichotoma for this larval trematode.

C. dichotoma a été trouvé libre, en mer, à Nice (3). C'est de cette espèce, que notre forme se rapproche le plus; Villot était aussi de cet avis dans sa communication préliminaire (4); mais dans son travail définitif, il donne au parasite de 'Scrobicularia tenuis', le nom de $C$. fissicauda (5). Or C. fissicauda (6) en diffère bien plus et est parasite dans un Gastropode pulmoné d'eau douce: Limnaea stagnalis.

(3) De La Valette St. George, loc. cit., pl. II, fig. I.

(4) Villot. Sur les migrations et les métamorphoses des Trématodes. Comptes Rendus Acad. Paris, t. Lxxxi, 1875, p. 475.

(5) Villot. Ann. d. Sc. nat. (Zool.), sér. 6, t. viII, p. 37.

(6) De La Valette St. George, loc. cit., pl. II, fig. 6 et $\mathrm{H}$.

\section{MATERIALS AND MeTHODS}

Living material was used to study the excretory system. Measurements were made on living specimens compressed between a glass slide and a cover-glass, as well as on whole mounts fixed in sublimate, stained with Giemsa, and mounted in Canada balsam. Tissues of infected specimens of Cardium edule were fixed in Bouin's solution. Serial sections $(6 \mu)$ were stained with Ehrlich's haematoxylin and eosin.

\section{OBSERVATIONS}

The development of Cercaria fulbrighti $\mathrm{n}$.sp. within the sporocyst differs from that of any other larval trematode yet recorded. In young developing cercariae forked tails appear (Text-figs. I $d-k$ and $2 \mathrm{~A}, \mathrm{~B} ; \mathrm{Pl}$. I, figs. I, 4), while fully developed cercariae (Text-figs. I $l$ and $2 \mathrm{~A}, \mathrm{C}$; Pl. I, figs. I, 2 and 4), although still within the sporocyst, never exhibit tails. Throughout the paper, the term 'fully developed cercariae' is used to designate cercariae, still enclosed within the sporocyst, which have had, in the course of their development, forked tails, but which no longer possess these structures. The tail of this larval trematode may degenerate completely while it is still within the sporocyst. The development and subsequent degeneration of the tail is illustrated in Text-fig. I; the drawings were made with the aid of a camera lucida using the same magnification. Both tailed and tail-less forms may be present within a sporocyst at the same time, with five being the maximum number of fully developed cercariae. Fork-tailed cercariae, capable of active swimming (provided the tail has not started to degenerate), may be liberated from the sporocyst. However, the free-swimming tailed forms, thus far observed, were not as well-developed as compared with cercariae whose tails had degenerated and which were still within the sporocyst. From these observations the possibility of two types of life-history arises; namely, one type in which the free-swimming or tail-less larvae enter a second inter- 
mediate host, and a second type in which the tail-less larvae are transferred directly to the final host.

Of the 420 cockles collected at Millbrook, five ( $1 \cdot 2 \%$ ) were found to contain sporocysts of this species, and in four of these cockles, sporocysts of at least one other cercaria were found. There were two double (Pl. I, fig. I) and two triple infections. In addition to $C$. fulbrighti, both double infections contained 'Bucephalus haimeanus', while 'B. haimeanus' and Cercaria cambrensis were included in the two triple infections.
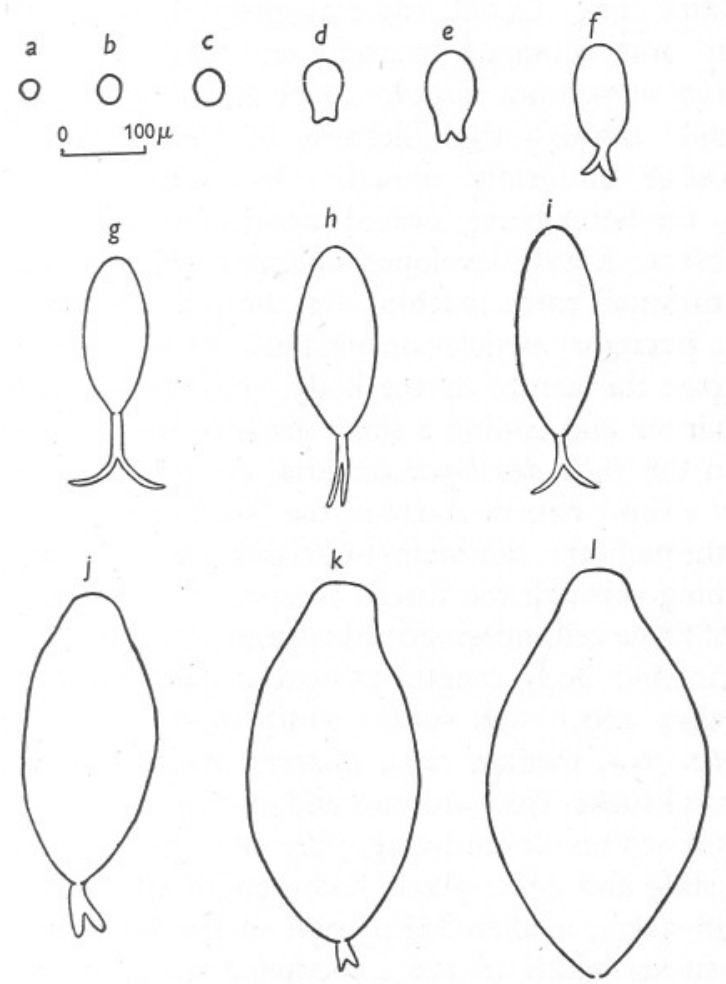

Text-fig. I. Cercaria fulbrighti $\mathrm{n}$.sp.; development and subsequent degeneration of the tail which occur within the sporocyst (camera lucida drawings made at the same magnification).

The sporocysts of $C$. fulbrighti are capable of movement by means of simultaneously expanding and contracting parts of the body-wall. The entire body-wall, with the exception of a snout-like structure (Pl. I, fig. I), is involved in such movements. The snout-like structure is pierced by an opening leading into the body cavity. Sporocysts of this species are very numerous, but never quite so concentrated within the individual Cardium as those of 'Bucephalus haimeanus' (P1. I, fig. I); the latter trematode, the most common in the cockles examined, occurred in $26.4 \%$ of the specimens. 


\section{Cercariae fulbrighti n.sp.}

(Text-figs. I and 2; P1. I)

Specific diagnosis. Marine, nonoculate, distome cercariae developing within irregularly ovoid sporocysts. Partially developed cercariae having distally forked-tails (Text-figs. I $d-k$ and $2 \mathrm{~A}, \mathrm{~B}$; Pl. I, figs. I, 4); fully developed cercariae tail-less (Text-figs. I $l$ and $2 \mathrm{~A}, \mathrm{C}$; Pl. I, figs. I, 2 and 4) while still within the sporocyst; sporocyst liable to contain both tailed and tail-less forms at the same time. Cuticle covering the body of the fork-tailed forms showing small dots arranged densely and regularly (P1. I, figs. 2, 3), this pattern seen in sections appears to be the surface view of fine striae passing obliquely through the thickness of the cuticle; cuticle of fully developed cercariae uniformly spined. Oral sucker slightly larger than ventral sucker, the latter being located posterior to the centre of the body. Prepharynx absent; a well-developed pharynx present leading into a wide oesophagus; intestinal caeca reaching just beyond the anterior edge of the ventral sucker. Excretory vesicle conspicuous, the lateral branches extending forward well past the centre of the body, converging before reaching the level of the pharynx and ending a short distance from the mid-point of the oesophagus; in the fully developed cercaria, the terminal vesicle opening to the exterior by a short narrow duct; in the tailed form, the caudal excretory tube passing through the tail stem bifurcating at its distal end with each branch continuing through the furcae to open to the exterior at their tips; thirteen pairs of flame cells observed. Measurements based on five fixed, fully developed specimens: body length $258-408 \mu$, median $328 \mu$; body width I 52-I96 $\mu$, median I60 $\mu$; oral sucker width 68-82 $\mu$, median $72 \mu$; ventral sucker width $62-76 \mu$, median $70 \mu$; pharynx width $20-24 \mu$, median $22 \mu$; distance of ventral sucker from anterior end of body $\mathrm{I} 24-208 \mu$, median $\mathrm{I} 64 \mu$. Measurements based on eleven living, fully developed specimens compressed between glass slide and cover-glass: body length $440-596 \mu$, median $536 \mu$; body width $248-320 \mu$, median $288 \mu$; oral sucker width IOO-I $32 \mu$, median I $20 \mu$; ventral sucker width $88-\mathrm{I} 26 \mu$, median I04 $\mu$; pharynx width $28-36 \mu$, median $32 \mu$; distance of ventral sucker from anterior end of body $268-356 \mu$, median $3 \mathrm{I} 2 \mu$. Measurements based on three tailed specimens: body length IOO-I $24 \mu$, median $\mathrm{I} 20 \mu$; body width $60-80 \mu$, median $64 \mu$; oral sucker width $28-34 \mu$, median $32 \mu$; ventral sucker width $28-32 \mu$, median $30 \mu$; tailstem length $40-52 \mu$, median $44 \mu$; tail stem width $\mathrm{I} 2-\mathrm{I} 8 \mu$, median $\mathrm{I} 6 \mu$; furca length $44-80 \mu$, median $48 \mu$.

Sporocyst. Sporocysts numerous and somewhat irregularly ovoid; capable of independent movement by means of projecting parts of the body-wall; a definite snout-like structure present (Text-fig. $2 \mathrm{~A}, s n$ ); relatively few fully developed cercariae in any one sporocyst, five being the maximum number observed; both cercariae and daughter sporocysts developing within the mother sporo- 


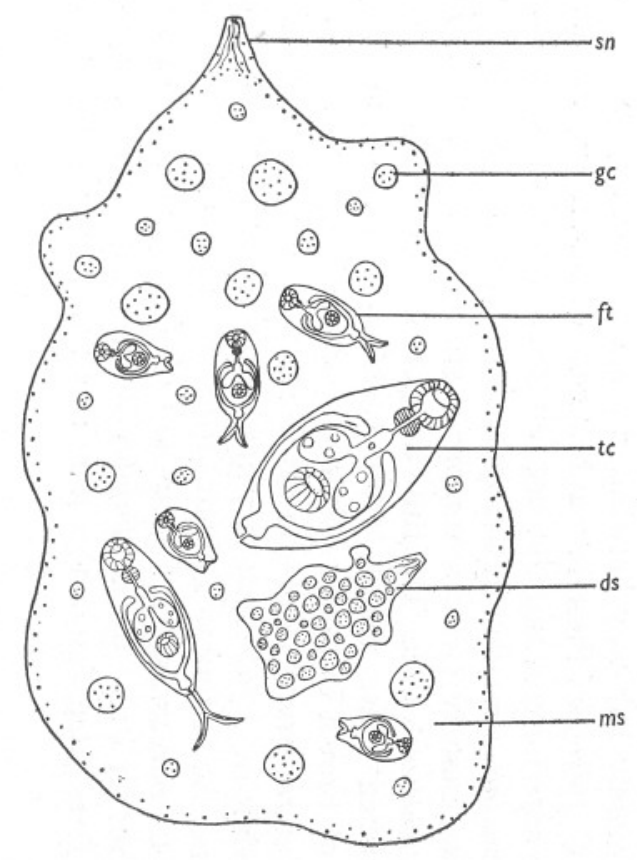

A

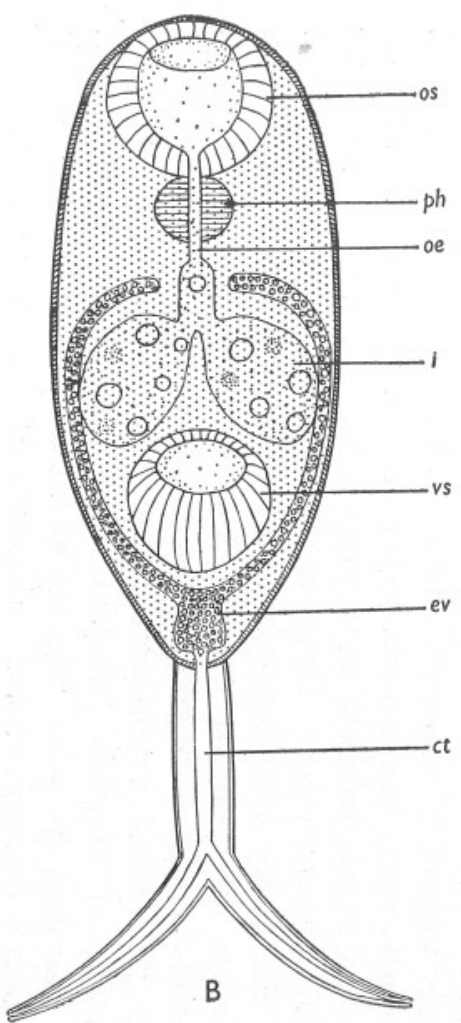

B

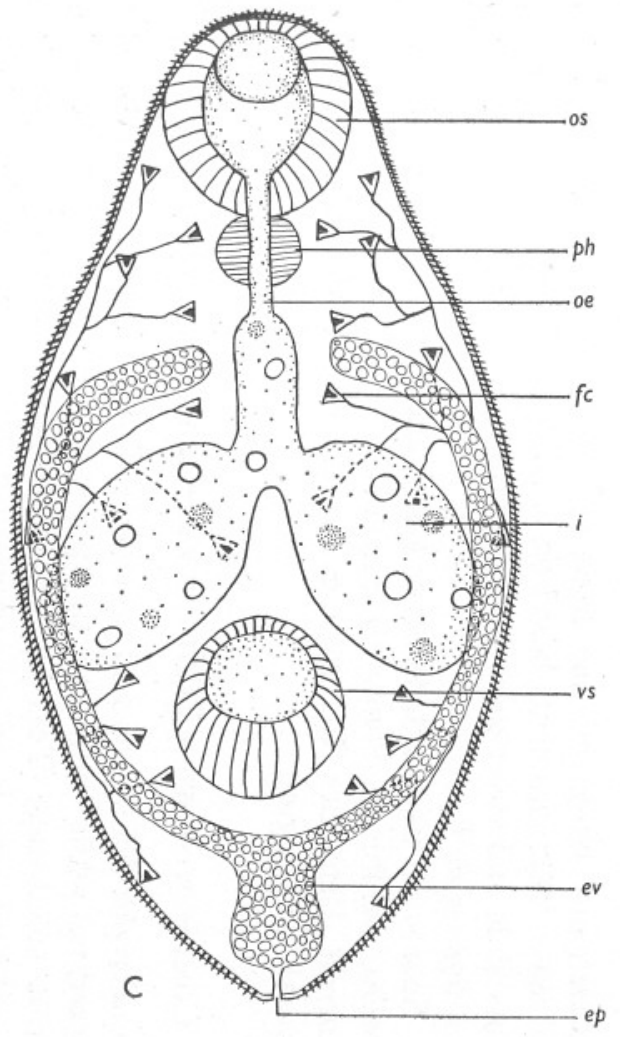

0
0
0
0
0
0
0
0
0
0
0
-1
-1

Text-fig. 2. Cercaria fulbrighti n.sp. A, sporocyst containing daughter sporocyst and cercariae in various stages of development. B, cercaria before degeneration of tail begins. C, cercaria after degeneration of tail is completed. The excretory system is incompletely shown as the granules within the excretory vesicle obscured parts of some of the flame cell canals. (All figures are semi-diagrammatic.) $c t$, caudal excretory tube; $d s$, daughter sporocyst; $e p$, excretory pore; $e v$, excretory vesicle; $f c$, flame cell; $f t$, furcocercous cercaria; $g c$, germ cell; $i$, intestinal caecum; $m s$, mother sporocyst; oe, oesophagus; os, oral sucker; $p h$, pharynx; $s n$, snout; $t c$, tail-less cercaria; $v s$, ventral sucker. 
cyst. Measurements based on one fixed specimen: body length I4I6 $\mu$; body width $768 \mu$. Measurements based on one living specimen compressed between glass slide and cover-glass: body length $\mathrm{I} 250 \mu$; body width $880 \mu$.

Host. Cardium edule L.

Habitat. Sporocysts in gonad, digestive gland, and upper part of foot.

Type locality. Millbrook, Plymouth, England.

Type material. Reference No.: I952, 6, 26, I/2, British Museum (Natural History), South Kensington.

\section{Comparisons with Previously Described Cercariae}

Cercaria fulbrighti differs from all previously described cercariae in that it loses its forked tail while still within the sporocyst. It was first thought that either the fork-tailed stage (Text-fig. 2B), or the fully developed stage (Textfig. 2 C), might have been described previously by a worker who failed to find both forms in the sporocyst. However, a search of the literature revealed no such description: there is no larval trematode which corresponds in structural detail to either stage of $C$. fulbrighti. But, $C$. dichotoma Müller, as described by Lebour (1908, I9I2) from Scrobicularia tenuis, appears to be very like the tailed form of Cercaria fulbrighti in its proportions and in the arrangement of the caudal excretory canals. However, because of certain morphological differences, the author feels justified in separating these forms specifically. Lebour refers to the sporocyst stage of $C$. dichotoma as 'structureless', an impression which could not be given by the sporocyst of the species described in this paper, for it shows a well-defined snout-like projection (Text-fig. 2A), and the cuticle of Cercaria fulbrighti shows the characteristic pattern previously described (p. 320), whereas no mention of such markings is made in Lebour's description of $C$. dichotoma Müller. Lebour's figure of C. dichotoma shows the lateral branches of the excretory vesicle diverging laterally approximately half-way between the anterior and posterior ends of the body. In C. fulbrighti these lateral branches extend nearly two-thirds of the way to the anterior end and converge almost to touch the oesophagus.

Three Gymnophallus cercariae, in the sporocyst stage, have been reported from Cardium edule; namely, Cercaria margaritae sp.inq. of Lebour, C. strigata Lebour, and C. cambrensis Cole. The fully developed cercaria of $C$. fulbrighti can be distinguished quite readily from each of these. $C$. margaritae possesses a pair of brown eye-spots while $C$. fulbrighti does not. Also, in the former, the lateral branches of the excretory vesicle reach to the level of the pharynx, while in C. fulbrighti they never extend beyond the mid-point of the oesophagus. According to Lebour (I9I2), the ratio of the oral to the ventral sucker of $C$. margaritae is $2: 3$, but, as Cole (1938) pointed out, this is probably a misprint for $3: 2$. In $C$. fulbright $i$ this ratio is approximately $9: 8$. For C. strigata, Rees (I939) gives this ratio as $9: 5$. Also, she reported the 
flame-cell formula to be $2[(2+2)+(2+2)]=I 6$, while in $C$. fulbrighti the total number of flame cells observed was 26 . However, it should be mentioned that the granules within the excretory vesicle obscured parts of the excretory system and prevented the tracing of all the canals of the flame cells. Specimens of both $C$. cambrensis and C. fulbrighti were observed in the same cockles and they are surely different species. The two species can be separated easily by the size and shape of their excretory vesicles: the lateral branches of this vesicle of the former larva occupy most of the body and extend to the level of the pharynx. In the tailed Gymnophallus, the lateral branches of the excretory vesicle are much smaller and never extend beyond the mid-point of the oesophagus. Also, the latter is much the larger and has (I) a longer oesophagus, and (2) larger suckers, which can be seen by the following measurements comparing the sucker widths with the body length. The measurements for C. cambrensis are Cole's (1938):

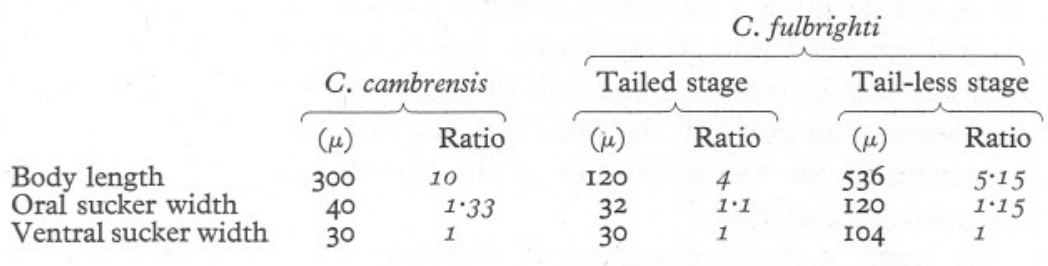

\section{Discussion}

Lühe (1909) placed those forms in which a tail is not developed in the Cercariaea group. He described the Furcocercous cercariae in the following words:

Distome Cercarien mit langem, an seinem freien Ende gegabeltem Schwanze, in welchen der schlanke Körper nicht zurückgezogen werden kann. ${ }^{1}$ Entwickelung meist in sehr langgestreckten Sporocysten, welche (ob bei allen Arten?) selbständig beweglich sind, nur bei einer Art angeblich in Redien.

\footnotetext{
${ }^{1}$ Vgl. hierzu auch die vorstehende C. mirabilis.
}

Lebour (I9I2), reviewing the British marine cercariae, placed the tail-less forms in the Gymnophallus group and defined them as follows:

Cercaria tail-less, developed (in the only species in which the sporocysts are known) in more or less spherical sporocysts in Pelecypoda. Oval body covered with spines. No prepharynx, conspicuous pharynx : short and broad intestinal caeca seldom reaching beyond ventral sucker. Ventral sucker always behind centre of body. Excretory vesicle large, forked, reaching far forward anteriorly.

She assigned the fork-tailed form (Cercaria dichotoma Müller) to a separate group and stated that in structure this group was closely allied with the Gymnophallus group. 
Sewell (1922), modifying Lühe's scheme of classification somewhat, placed those forms 'in which development occurs in rediae or in simple sporocysts, and in which all trace of a tail is absent' in the Cercariaea group. He revised and extended the three groups of Furcocercous cercariae created by Cort (1917), placing in group I the apharyngeate, brevifurcous cercariae and in group 2 the pharyngeate, longifurcate cercariae (with the exception of C. indica XXII which he included in the 'Baiswan' subgroup of group 2, although it had certain characteristics in common with the brevifurcous cercariae). Group 3 includes those forms which Sewell believed to have originated from a monostome stock and in which the acetabulum was extremely small and rudimentary or completely absent.

Miller (1926), in his monograph on Furcocercous cercariae, modified Sewell's scheme of classification and considered the presence or absence of a pharynx to be of more significance than the presence or absence of a ventral sucker in determining a natural scheme of classification. He subdivided the pharyngeal cercariae into 'brevifurcate' and 'longifurcate' larvae, the former with 'furcae usually less than one-half the tail-stem length' and the latter with 'furcae longer than one-half the tail-stem, sometimes exceeding it'. He made a comparison of the characteristics of the brevifurcate and the longifurcate larvae known at that time.

At one stage in its development $C$. fulbrighti has many characteristics in common with Miller's 'pharyngeal longifurcate distome cercariae', but differs from this group in certain respects, the most notable difference being that in this cercaria the excretory openings are at the tips of the furcae while in Miller's longifurcate larvae the openings are typically mid-furcal. In a later stage, when the tail disappears and spines develop, C. fulbrighti has all the characteristics of Lebour's Gymnophallus group. These characteristics were quoted previously.

Cort (I918), discussing the tail-less cercariae, points out that the provisional Cercariaeum, based only on the absence of the tail in the fully developed cercaria within the sporocyst or redia, is evidently an unnatural group. It may yet be assumed that members of this group, however unnatural, have evolved from cercarial ancestors which possessed tails. As shown above, the forked tail of Cercaria fulbrighti degenerates while still within the sporocyst. The tail-less cercaria cannot therefore have a free-swimming stage. This much is evident, even though information is lacking on the further stages of this species.

Since C. fulbrighti presumably develops into a member of the genus Gymnophallus Odhner (1900), there appears to be sufficient evidence to suggest a phylogenetic relationship between this group and certain of the furcocercous cercariae.

As was already noted, the adult stage of Cercaria fulbrighti is almost certainly a species of Gymnophallus. It is interesting to note the remarkable similarity between this larva and the adult stage of G. choledochus Odhner 
which Nicoll (1923) recorded from the gall-bladders of three British birds: the common sheld duck, Tadorna tadorna (L.); the eider duck, Somateria mollissima (L.); and, the king eider, S. spectabilis (L.).

\section{SUMMARY}

A summary of the trematode parasites which have been recorded from the cockle is given.

A furcocercous, Gymnophallus larva, Cercaria fulbrighti n.sp., from the marine bivalve Cardium edule L., is described from Plymouth, England. The tail of this larva may degenerate completely while the cercaria is still within the sporocyst.

Simultaneous development of more than one species of cercaria has been recorded in four out of 420 specimens of C. edule L. Two double and two triple infections were found.

Available evidence suggests a phylogenetic relationship between the Gymnophallus group and certain of the Furcocercous cercariae.

\section{REFERENCES}

Cole, H. A., 1938. On some larval trematode parasites of the mussel (Mytilus edulis) and the cockle (Cardium edule). Part II. A new larval Gymnophallus (Cercaria cambrensis) sp.nov. from the cockle (Cardium edule). Parasitology, Vol. 30, pp. 40-3.

CORT, W. W., I9I7. Homologies of the excretory system of the forked-tailed cercariae. Fourn. Parasitology, Vol. 4, pp. 48-57.

- 1918. A new Cercariaeum from North America. Fourn. Parasitology, Vol. 5, pp. 86-90.

JoHnStone, J., I904. Internal parasites and diseased conditions of fishes. Rep. Lancs. Sea-Fish Lab., p. 107.

Lebour, M. V., I908. Trematodes of the Northumberland coast, No. II. Trans. Nat. Hist. Soc. Northumberland, Durham E Newcastle, N.S., Vol. 2, pp. 7-9, 13-I4.

- I9I2. A review of the British marine cercariae. Parasitology, Vol. 4, pp. 4I6-56.

Lebour, M. V. \& Elmhirst, R., I922. A contribution towards the life history of Parorchis acanthus Nicoll, a trematode in the herring gull. Fourn. Mar. Biol. Assoc., Vol. 12, pp. 829-32.

LÜHE, M., 1909. Parasitische Plattwürmer, I: Trematodes. Die Süsswasserfauna Deutschlands. Bd. I7, 217 pp.

Miller, H. M., I926. Comparative studies on furcocercous cercariae. Ill. Biol. Monogr., Vol. IO, II2 pp.

Nicoll, W., I923. A reference list of the trematode parasites of British birds. Parasitology, Vol. 15, pp. I5 I-202.

OdHner, T., I900. Gymnophallus, eine neue Gattung von Vogeldistomen. Centralblatt $f$. Bakteriologie, Parasitenkunde u. Infektionskrankheiten. Abt. I., Bd. 28, pp. $12-23$.

Pelseneer, P., I906. Trématodes parasites de mollusques marins. Bull. Sci. Fr. Belg., T. 40 , pp. I6I-86. 
ReEs, G., I939. Cercaria strigata Lebour from Cardium edule and Tellina tenuis. Parasitology, Vol. 3I, pp. 458-63.

Sewell, R. B. S., 1922. Cercariae indicae. Ind. Fourn. Med. Research, Vol. Io (Suppl. No.), 370 pp.

\section{EXPLANATION OF PLATE I \\ Cercaria fulbright $\mathrm{n} . \mathrm{sp}$.}

Fig. I. Section through the upper part of the foot of Cardium edule L. showing double trematode infection; $a$, sporocyst of Cercaria fulbrighti; $b$, sporocyst of 'Bucephalus haimeanus'; $c$, fork-tailed stage of Cercaria fulbrighti; $d$, fully developed stage of $C$. fulbrighti; $e$, cercaria of 'Bucephalus haimeanus'; $f$, muscle layer of foot.

Fig. 2. Tail-less cercaria before spines develop.

Fig. 3. Characteristic markings on body of cercaria before spines develop.

Fig. 4. Part of sporecyst showing both tailed (a) and fully developed (b) cercariae.

Figs. I and 3 have been made from sections stained with Ehrlich's haematoxylin and eosin. Figs. 2 and 3 were made from living material compressed between glass slide and cover-glass with Fig. 3 being made under oil immersion $\left(\frac{1}{12}\right)$. 

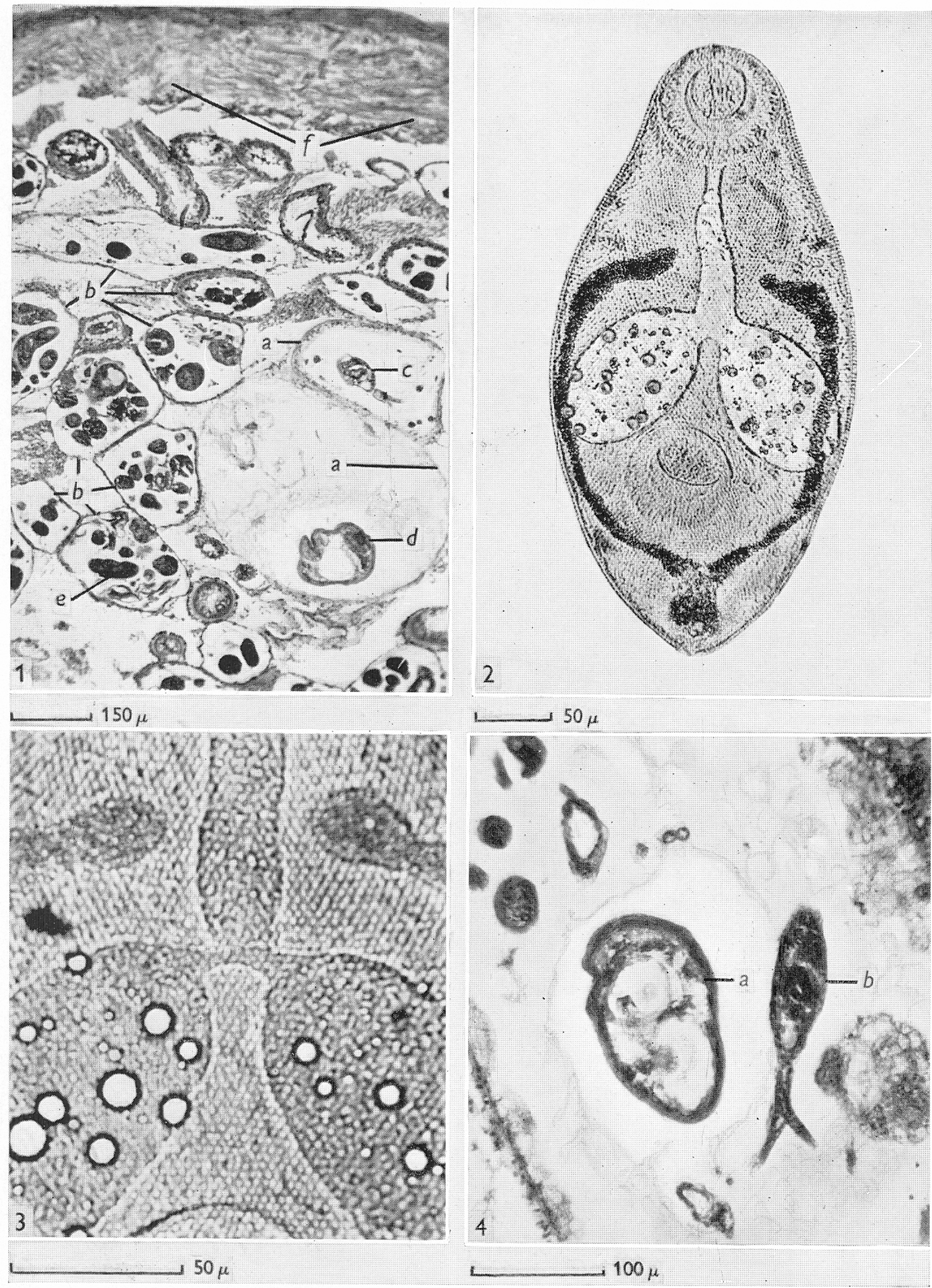